\title{
Bronchial provocation testing in the diagnosis of occupational asthma due to latex surgical gloves
}

\author{
G. Pisati*, A. Baruffini*, F. Bernabeo*, R. Stanizzi**
}

Bronchial provocation testing in the diagnosis of occupational asthma due to latex surgical gloves. G. Pisati, A. Baruffini, F. Bernabeo, R. Stanizzi. CERS Journals Ltd 1994. ABSTRACT: In sensitized subjects, provocation tests to latex may induce severe systemic reactions and even anaphylactic shock. It is probable that part of the risk is due to the difficulty in grading the stimulating dose and in starting from very low levels of exposure.

To identify the aetiological agent of work-related asthma in four nurses with previous allergic contact urticaria to latex surgical gloves dusted with cornstarch powder, we performed a specific bronchial provocation test study, based on exposure on three different days to nonpowdered latex surgical glove extract, powdered latex surgical glove extract and cornstarch powder extract, respectively. Extracts were nebulized in increasing concentrations in a $7 \mathrm{~m}^{3}$ challenge room, in the absence of the patients. The initial extract concentration was a tenfold dilution of the predetermined skin test end-point in the individual undergoing challenge, and the highest concentration was the undiluted extract. After exposure, the patients' forced expiratory volume in one second $\left(F_{E V}\right)$ was monitored for $2 \mathrm{~h}$. If $\mathrm{FEV}_{1}$ decreased by at least $15 \%$, the next scheduled exposure was not carried out and $F E V_{1}$ was monitored over a period of $24 \mathrm{~h}$.

Whereas nebulization of cornstarch powder extract caused no bronchial reaction in the patients, nebulization of nonpowdered latex surgical glove extract induced immediate bronchoconstriction in two subjects as an undiluted solution, and nebulization of powdered latex surgical glove extract induced immediate bronchoconstriction in all subjects at the 1:10 dilution. No systemic reaction was elicited by the bronchial provocation challenges.

Our results demonstrate that airborne powder from latex gloves can be an inhalative occupational hazard. Latex, absorbed by the cornstarch powder and then airborne when gloves were handled, was the causative agent of the respiratory events in our patients. The standardized method that we used minimizes the risk of eliciting systemic reactions when performing specific bronchial provocation tests to latex.

Eur Respir J., 1994, 7, 332-336. *Servizio di Medicina del Lavoro, **Servizio
Allergologia, Ospedale di Lecco, Lecco, Italy.

Correspondence: G. Pisati

Servizio di Medicina del Lavoro

Ospedale di Lecco

C.so P. Sposi 1

22053 Lecco

Italy

Keywords: Bronchial provocation test latex

occupational asthma

Received: May 241993

Accepted after revision August 191993
In the past few years, numerous immediate hypersensitivity reactions to natural rubber resulting from occupational exposure have been reported in health care personnel [1, 2], and in workers in glove-manufacturing plants [3]. Contact urticaria has been reported as the most frequent clinical manifestation, but several cases of rhinitis, conjunctivitis, angio-oedema and asthma have also been reported, as part of the generalized reactions following contact with latex [4-7], or as a result of inhalation of airborne latex allergens [8, 9].

Usually, diagnosis of allergic reactions to latex has been based on skin prick tests and/or identification of specific immunoglobulin $\mathrm{E}$ ( $\operatorname{IgE}$ ) in the serum of patients. In a few subjects, provocation tests to latex have also been carried out, but the risk of inducing anaphylactic reactions when performing them have been stressed by many authors $[1,4,5,10,11]$. It is likely that part of the risk is due to the difficulty in grading the stimulating dose and in starting from very low levels of exposure.

Recently, we had to determine the causative agent of work-related asthma in four nurses at our hospital, with previously diagnosed allergic contact urticaria to powdered (cornstarch) latex surgical gloves. We could exclude the possibility that direct skin contact with latex was responsible for their asthmatic attacks because, after the onset of dermatitis, two nurses wore cotton undergloves inside the latex gloves, and the other two used synthetic non-latex gloves. We suspected that their respiratory troubles were due to inhalation of latex allergens transferred from gloves to powder, which may become airborne when the gloves are handled, as demonstrated by SwANSON et al. [12]. 
To verity this hypothesis, we developed a specific bronchial challenge study. This standardized procedure, which minimizes the risk of systemic reactions, is described in the present paper.

\section{Material and methods}

\section{Subjects}

Four female nurses from our hospital started suffering from work-related asthma 1.6 \pm 0.8 yrs (mean \pm SD) after they had allergic contact urticaria to latex surgical gloves lubricated with cornstarch powder. During asthmatic attacks, wheezing was associated with cough, facial redness, sneezing and ocular itching, but not with generalized urticaria, angio-oedema or tachycardia. No patient had ever had anaphylactic shock. Patch tests to accelerators of rubber (thiouram, mercapto mixtures, benzothiazoles, diphenylguanide, thioureas) and to other additives (zinc oxide, thiocarbamates, paraphenylenediamine) were negative in all patients, as was specific cornstarch serum IgE. All subjects had elevated specific latex IgE (Pharmacia Cap System, Uppsala, Sweden) and three also had elevated total serum IgE (table 1). Two patients were atopic (one had sensitization to grass, birch and parietaria pollens; the other to birch pollens) with seasonal rhinitis; and one had contact eczema from nickel, but when away from work all were free from asthmatic attacks and had normal lung function. In two nurses, we documented an acute fall in $\mathrm{FEV}_{1}$ of at least $20 \%$ during the workshift; the other two reported onset of cough and wheezing 10-15 min after they had handled latex gloves wearing cotton undergloves, or after their colleagues had worn latex gloves in the same room.

A methacholine inhalation challenge, performed according to the protocol of the Italian Societies of Respiratory Pathophysiology and of Occupational Medicine [13], demonstrated in all subjects a nonspecific bronchial reactivity in the range of asthmatic patients (i.e. cumulative dose of methacholine producing a $15 \%$ fall in $\mathrm{FEV}_{1}$ lower than $1 \mathrm{mg}$ ).

\section{Substances for in vivo tests}

Powdered latex surgical glove extract, was prepared according to the method described by TURJANMAA et al. [10]: $1 \mathrm{~g}$ of freshly cut glove pieces from the same trade- mark gloves used in the workplace (Ansell, Ansell Rubber Co. Ltd, Malacca, Malaysia) were incubated for $2 \mathrm{~h}$ at room temperature in $20 \mathrm{ml}$ of sterile phosphate buffer, $\mathrm{pH}=6.9$. The solution was first dialysed against phosphate buffer and then filtered through Durapore Millex HV $0.45 \mu \mathrm{m}$.

Nonpowdered latex glove extract was prepared in the same way as described above, from nonpowdered latex gloves used in our hospital (Ansell No Powder, Ansell Rubber Co. Ltd, Malacca, Malaysia).

To prepare cornstarch powder extract - $1 \mathrm{~g}$ of powder supplied from the glove-manufacturing company was incubated overnight in $30 \mathrm{ml}$ of sterile phosphate buffer, $\mathrm{pH}=6.9$. The solution was then dialysed against phosphate buffer and filtered through Durapore Millex HV $0.45 \mu \mathrm{m}$.

To prepared cornstarch powder solution $-0.5 \mathrm{~g}$ of powder supplied from the glove-manufacturing company was dissolved in $1 \mathrm{ml}$ of sterile physiological saline.

Zero order and second derivative UV spectra were performed on 1:20 dilution of all extracts, in order to record a "fingerprint" of each.

\section{Study performed}

Skin tests. Prick test were performed with: 1) commercially available natural latex extract (Lofarma Allergeni Milano, Italy); 2) nonpowdered latex surgical glove extract at 1:1000, 1:100 and 1:10 dilutions in sterile physiological saline, and undiluted; 3) powdered latex surgical glove extract at 1:1000, 1:100 and 1:10 dilutions in sterile physiological saline, and undiluted; 4) undiluted cornstarch powder extract; 5) cornstarch powder solution; and 6) physiological saline and histamine $\left(10 \mathrm{mg} \cdot \mathrm{ml}^{-1}\right)$ as controls.

A prick test reaction was regarded as doubtful (+) when it was less than half the reaction caused by histamine control solution; weak positive $(++)$ when it was equal to half the reaction to histamine; clear positive $(+++)$ when the reaction was the same as that brought about by histamine; and strong positive $(++++)$ when the reaction was greater than the reaction to histamine [14]. Responses were interpreted after $15 \mathrm{~min}$.

Occupational-type bronchial challenge test. According to the method described by JAEGER et al. [9], in a $7 \mathrm{~m}^{3}$

Table 1. - Characteristics of the four nurses suffering from contact urticaria to latex surgical gloves and work-related asthma

\begin{tabular}{lclcccc}
\hline $\begin{array}{l}\text { Case } \\
\text { No. }\end{array}$ & $\begin{array}{c}\text { Age } \\
\text { yrs }\end{array}$ & Hospital department & $\begin{array}{c}\text { Atopic } \\
\text { state }\end{array}$ & $\begin{array}{c}\text { Total IgE } \\
\text { kU. } l^{-1}\end{array}$ & $\begin{array}{c}\text { IgE to latex } \\
\text { kU.l-1 }\end{array}$ & $\begin{array}{c}\text { PD }_{15} \text { methacholine } \\
\mu g\end{array}$ \\
\hline 1 & 26 & Neurological surgery & No & 138 & 1.1 & 500 \\
2 & 25 & Delivery room & Yes & 764 & 3.5 & 650 \\
3 & 24 & Emergency department & Yes & 558 & 1.8 & 250 \\
4 & 28 & Infectious diseases & No & 861 & 3.5 & 800
\end{tabular}

IgE: immunoglobulin $\mathrm{E} ; \mathrm{PD}_{15}$ : provocative dose of methacholine producing a $15 \%$ fall in forced expiratory volume in one second from baseline. 
Table 2. - Prick test results in the four patients

\begin{tabular}{|c|c|c|c|c|c|c|c|c|c|c|c|}
\hline \multirow{2}{*}{$\begin{array}{l}\text { Case } \\
\text { No. }\end{array}$} & \multirow[t]{2}{*}{$\begin{array}{l}\text { Natural } \\
\text { latex }\end{array}$} & \multicolumn{4}{|c|}{$\begin{array}{c}\text { Nonpowdered } \\
\text { latex surgical glove extract }\end{array}$} & \multicolumn{3}{|c|}{$\begin{array}{c}\text { Powdered } \\
\text { latex surgical glove extract }\end{array}$} & \multirow[b]{2}{*}{ UD } & \multicolumn{2}{|c|}{$\begin{array}{l}\text { Cornstarch } \\
\text { powder }\end{array}$} \\
\hline & & $1 / 1000$ & $1 / 100$ & $1 / 10$ & UD & $1 / 1000$ & $1 / 100$ & $1 / 10$ & & Sol & Ext \\
\hline 1 & +++ & - & - & - & ++ & - & ++ & +++ & +++ & - & - \\
\hline 2 & ++++ & - & - & - & ++ & + & ++ & +++ & ++++ & - & - \\
\hline 3 & ++++ & - & + & + & ++ & + & ++ & +++ & ++++ & - & - \\
\hline 4 & +++ & - & - & - & ++ & + & ++ & ++ & +++ & - & - \\
\hline
\end{tabular}

Ext: extract; Sol: solution; UD: undiluted; +: doubtful, less than half the reaction caused by histamine control solution; ++: weak positive, equal to half the reaction to histamine; +++: clear positive, equal to reaction to histamine; ++++: strong positive, greater than reaction to histamine.

exposure chamber, after having worn latex-free gloves, the nurses handled an increasing number of the same powdered latex gloves used at work for $20 \mathrm{~min}$, unless there was an earlier appearance of bronchospasm documented by a $\geq 15 \%$ fall in $\mathrm{FEV}_{1}$ from baseline value. Airborne generated dust levels were measured. After exposure, $\mathrm{FEV}_{1}$ was monitored at 5, 10, 15, 30 and 60 min, and then hourly for $8 \mathrm{~h}$, and finally after $24 \mathrm{~h}$. As control test, on a different day, patients underwent a bronchial challenge to pure cornstarch powder supplied from the glove-manufacturing company.

Specific bronchial provocation tests. On 3 different days, with an interval of at least 4 days between challenges in the same individual, the four nurses were exposed to: 1) nonpowdered latex surgical glove extract; 2) powdered latex surgical glove extract; and 3) cornstarch powder extract, each nebulized in a $7 \mathrm{~m}^{3}$ challenge room. The sample solution was converted into a fine mist by means of a stainless steel nebulizer, supplied as standard equipment in atomic absorption spectrometers. The nebulizer operates by passing a fast stream of air over the end of a capillary tube dipping into the solution. Only the finest droplets in the mist $(<20 \mu \mathrm{m}$ in aerodynamic diameter) are carried into the challenge room atmosphere; the larger ones, which include most of the total volume, precipitate out and flow down the drain.

The patient was not in the challenge room when the nebulization was performed; she came into the room after the nebulization and remained there for $15 \mathrm{~min}$, unless there was an earlier appearance of wheezing and $\mathrm{a} \geq 15 \%$ fall in $\mathrm{FEV}_{1}$ from baseline value. After exposure, $\mathrm{FEV}_{1}$ was monitored at 5, 10, 15, 30, 60, 90 and $120 \mathrm{~min}$; if the fall in $\mathrm{FEV}_{1}$ was $<15 \%$, the nurse underwent the next scheduled nebulization. Each time $2 \mathrm{ml}$ of solution was delivered and, each time, the concentration of nebulized extract was tenfold that of the previous one. The initial extract concentration was a tenfold dilution of the predetermined skin test end-point in the individual undergoing challenge, and the highest concentration was the undiluted extract. If one nebulization caused a $\geq 15 \%$ fall in the patient's $F E V_{1}$, the next exposure was not done and $\mathrm{FEV}_{1}$ was monitored hourly for $8 \mathrm{~h}$ and finally after $24 \mathrm{~h}$. FEV measurements were carried out at the same pre-established times when the top concentration was reached without $\mathrm{a} \geq 15 \%$ fall in $\mathrm{FEV}_{1}$.

\section{Results}

Skin tests results are reported in table 2. All subjects had a clear positive reaction to prick test with commercial latex extract and no reaction to cornstarch extract and solution. Prick tests with nonpowdered latex surgical glove extract gave a positive reaction only when undiluted. Skin tests with powdered latex surgical glove extract gave a positive reaction from the 1:100 dilution.

The occupational-type bronchial challenge demonstrated that exposure to airborne dust from latex gloves was the causative agent of the patients asthma; in fact, handling powdered latex surgical gloves caused an isolated immediate bronchoconstriction in all patients (table 3). It was not due to a nonspecific airway irritant response, since exposure for $15 \mathrm{~min}$ to $3.5 \pm 1.9 \mathrm{mg} \cdot \mathrm{m}^{-3}$ (mean \pm SD 1.9) of pure cornstarch powder did not induce any reaction.

Results of specific bronchial challenges with nonpowdered and powdered latex surgical glove extracts and with cornstarch powder extract are shown in figure 1 . Exposure to nonpowdered latex surgical glove extract started from the nebulization of the 1:10 dilution; a significant bronchoconstriction was observed in two subjects with the undiluted extract. Exposure to powdered latex surgical glove extract started from the nebulization of the 1:1000 dilution; a significant bronchospasm was observed in all subjects at the 1:10 extract dilution. In three patients bronchial reactions had an isolated immediate temporal pattern, with spontaneous recovery within an hour. In one patient (case No. 3) bronchoconstriction persisted for $3 \mathrm{~h}$ before spontaneous return of $\mathrm{FEV}_{1}$ to baseline value. In all subjects, bronchospastic response

Table 3. - Occupational-type inhalation challenge test performed by handling powdered latex surgical gloves

\begin{tabular}{lcccc}
\hline $\begin{array}{l}\text { Case } \\
\text { No. }\end{array}$ & $\begin{array}{c}\text { Pairs of } \\
\text { gloves } \\
\mathrm{n}\end{array}$ & $\begin{array}{c}\text { Exposure } \\
\mathrm{min}\end{array}$ & $\begin{array}{c}\text { Dust level } \\
\mathrm{mg} \cdot \mathrm{m}^{-3}\end{array}$ & $\begin{array}{c}\% \text { fall } \\
\text { in FEV }\end{array}$ \\
\hline 1 & 10 & 6 & 7.4 & 25 \\
2 & 3 & 2 & 1.7 & 24 \\
3 & 18 & 10 & 3 & 40 \\
4 & 35 & 20 & 5.8 & 22 \\
\hline
\end{tabular}

$\mathrm{FEV}_{1}$ : forced expiratory volume in one second. 
a)

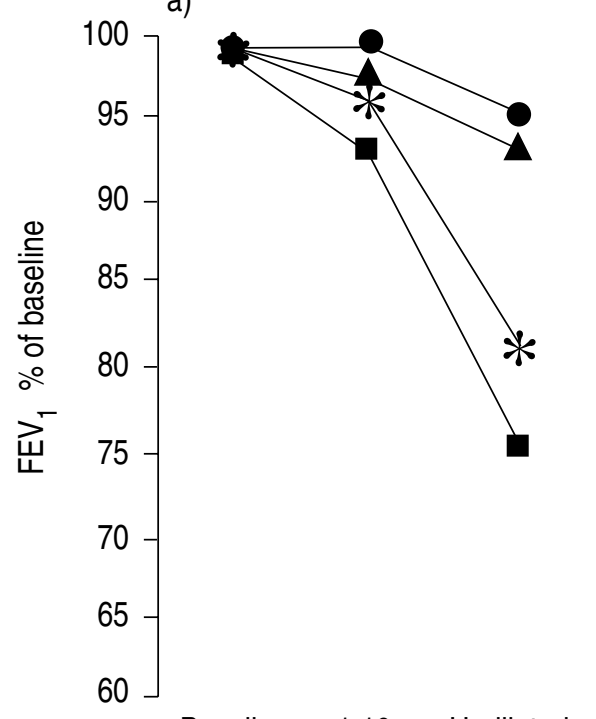

b)

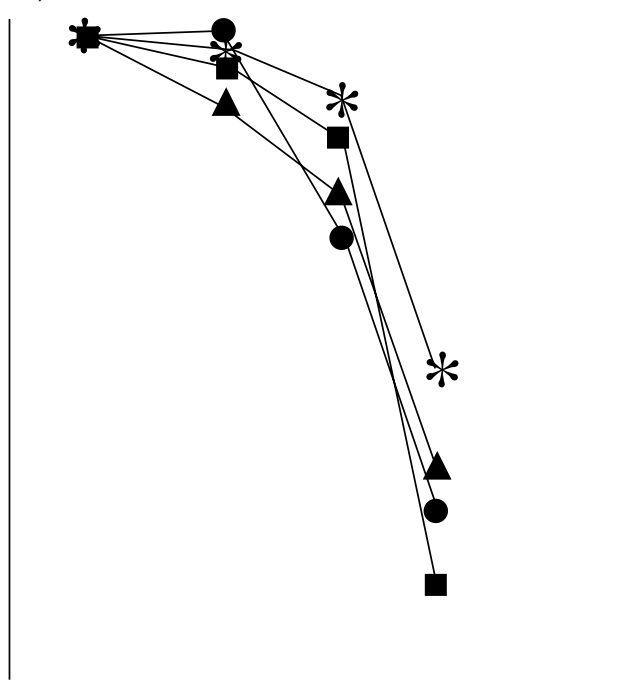

c)

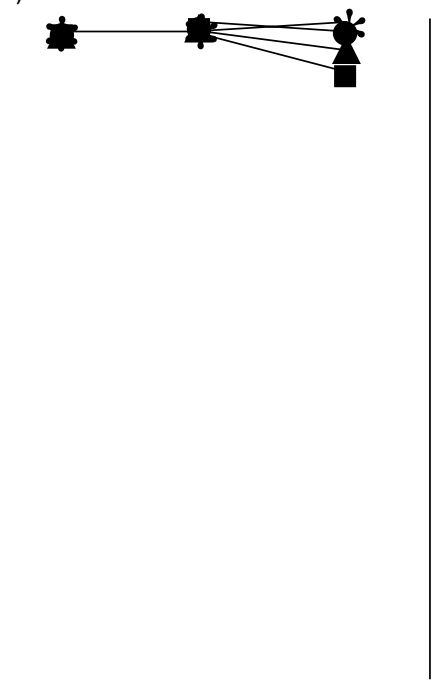

Fig. 1. - Change in lung function in the four nurses in the specific bronchial provocation tests: a) to nonpowdered latex surgical glove extract; b) to powdered latex surgical glove extract; and c) to cornstarch powder extract, each nebulized in a $7 \mathrm{~m}^{3}$ challenge room. $-\mathbf{\bullet}$ : Case No. 1 ; $-\mathbf{A}$ : Case

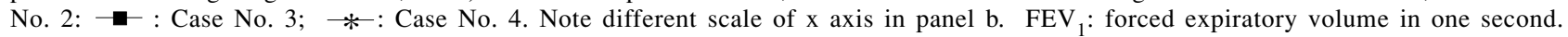

was associated with sneezing, rhinorrhoea and cough, but not with systemic reactions. Exposure to nebulized cornstarch powder extract induced no reaction.

\section{Discussion}

In the four patients studied, bronchial provocation testing was essential for determination of the specific agent of asthma and prevention of the disease. In fact, skin tests and specific $\operatorname{IgE}$ to latex were positive, but they were not sufficient to prove that latex was responsible for asthma, because patients had allergic urticaria to latex. The specific bronchial provocation test that we developed for the diagnosis of asthma consisted of exposure to airborne nebulized latex glove extracts.

So far, bronchial challenge tests have been performed by having patients with respiratory symptoms wear latex gloves [10], or handle powdered latex gloves [9], or inhale latex glove extract [8]. We decided not to use the first type of challenge in our patients because they no longer had skin contact with natural rubber gloves, as a result of their latex allergic dermatitis.

Though challenge by handling powdered latex gloves reproduces the risk encountered in the workplace, difficulties arise in standardizing exposure, since airborne dust levels are influenced by how patients handle the gloves and how much powder coats the internal side of gloves. As shown by our measurements, considerable amounts of powder can become airborne even from a few pairs of gloves, and this might result in unduly severe asthmatic or systemic reactions or in nonspecific airway irritant responses.

Latex glove extract in specific bronchial provocation test was first used by MARCos et al. [8], who made patients inhale aerosolized allergen in progressively increasing concentrations at tidal volume. We preferred exposure to latex glove extract nebulized in a challenge room, since this was more like the exposure encountered in the workplace. Although our subjects had never had systemic reactions after exposure to latex, for safety purposes we decided to nebulize extracts in their absence, starting from a tenfold dilution of the predetermined endpoint cutaneous threshold concentration. In this way, we could document specific bronchospasm to latex glove extract without any systemic reaction. If bronchial provocation tests must be carried out in subjects suffering from asthma associated with systemic manifestations, higher starting dilutions of extracts might be cautiously used.

Results of our study confirm previous observations [9, 12] that powder airborne from latex gloves can be an inhalative occupational hazard. Bronchoconstriction observed after challenges with powdered and nonpowdered glove extracts, but not after the cornstarch powder extract, demonstrates that latex was the causative agent of asthma. The airway reactions of the patients, which were more severe after exposure to powdered latex glove extract than after nonpowdered latex glove extract, strongly suggest that latex antigens may be absorbed by the cornstarch powder and then become airborne when gloves are handled. Results of prick tests with powdered and nonpowdered latex glove extracts support this finding. In agreement with other reports of allergy to latex [1,2], in our patients the clinical manifestations were IgE-mediated and atopy was present in a considerable proportion $(50 \%)$ of patients.

The natural course of latex allergy in our subjects indicates that worsening of contact dermatitis can be prevented by using non-latex gloves, or by wearing undergloves 
inside latex gloves. This approach does not, however, necessarily prevent onset of respiratory symptoms, since airways are not protected, and even indirect exposure to very low concentrations of allergen (such as those airborne when colleagues open a powdered glove package in the same room) can be sufficient to cause asthma in sensitized persons. Therefore, removal to areas where gloves are never or seldom used seems to be the most appropriate way of prevention of this occupational respiratory disease. As an alternative, but less satisfactory solution, the collegues of sensitized workers should be equipped with nonpowdered latex gloves and the sensitized persons should use non-latex gloves or wear undergloves inside nonpowdered latex gloves, in order to prevent both direct skin contact with latex and inhalation of powder airborne from powdered latex gloves.

\section{References}

1. Levy DA, Charpin D, Pecquet C, Leynadier F, Vervloet D. Allergy to latex. Allergy 1992; 47: 579-587.

2. Slater JE. Allergic rections to natural rubber. Ann Allergy 1992; 68: 203-208.

3. Tarlo SM, Wong L, Roos J, Booth N. Occupational asthma caused by latex in surgical glove manufacturing plant. J Allergy Clin Immunol 1990; 85: 626-631.

4. Wrangsjo K, Wahlberg J, Axelsson IGK. IgE-mediated allergy to natural rubber in 30 patients with contact urticaria. Contact Dermatitis 1988; 19: 264-271.

5. Sussman G, Tarlo S, Dolovich J. The spectrum of IgE- mediated responses to latex. J Am Med Assoc 1991; 265 : 2844-2847.

6. $\quad$ Slater JE. Rubber anaphylaxis. $N$ Engl J Med 1989; 27: 1127-1130.

7. Morales C, Badomba A, Carreira J, Sastre A. Anaphylaxis produced by rubber glove contact: case reports and immunological identification of the antigens involved. Clin Exp Allergy 1989; 19: 425-430.

8. Marcos C, Lazaro M, Fraj J, et al. Occupational asthma due to latex surgical gloves. Ann Allergy 1991; 67: 319-323.

9. Jaeger D, Kleinhans D, Czuppon A, Baur X. Latexspecific proteins causing immediate-type cutaneous, nasal, bronchial and systemic reactions. J Allergy Clin Immunol 1992; 89: 759-768.

10. Turjanmaa K, Reunala T, Rasanen L. Comparison of diagnostic methods in latex surgical glove contact urticaria. Contact Dermatitis 1988; 19: 241-247.

11. Axelsson JGK, Johansson SGO, Wrangsjo K. IgE-mediated anaphylactoid reactions to rubber. Allergy 1987; 42: 46-50.

12. Swanson MC, Bubak ME, Hunt LW, Reed CE. Occupational respiratory allergic disease from latex (Abstract). J Allergy Clin Immunol 1992; 89: 227.

13. Gruppo di lavoro per la normalizzazione dei tests di provocazione bronchiale aspecifica della Società Italiana di Fisiopatologia Respiratoria e della Società Italiana di Medicina del Lavoro e Igiene Industriale. Protocollo per l'esecuzione del test di provocazione bronchiale aspecifica. Fisiopatologia Respiratoria 1982; 3: 3-15.

14. Aas K, Belin L. Standardization of diagnostic work in allergy. Int Arch Allergy 1973; 45: 57-60. 